the physician who has not studied this subject. It should be of great value to general practitioners as it gives him quite enough information as to how he can apply this aid to healing in those of his patients whose physical disability is aggravated by the simpler types of psychic trauma.

The book is also of use in indicating to the physician himself minor shortcomings that may be present in his own psychological make-up, the understanding of which cannot fail to make him a better doctor.

\section{PSYCHOLOGY AND PSYCHOTHERAPY.-By William}

Brown, D.M. (Oxon.), D.Sc. (Lond.), F.R.C.P. Fourth Edition. 1940. Edward Arnold and Company, London. Pp. viii plus 260 . Price, 12s. 6d.

Although the title of this book indicates its concern with the treatment of mental disorder, it actually deals with only a few aspects of treatment. Occupational therapy, hydrotherapy and 'shock' therapy, to mention a few well-established forms of mental therapy, are not even mentioned. On the other hand, psychoanalysis, hypnosis and so on are discussed at some length. The psychoanalytical psychology of Freud comes in for a good deal of adverse criticism, but the author overlooks entirely the one great flaw in psychoanalysis, i.e., its disinclination to bring its principles into relation with the mental activities of non-human animals. The author appears to entertain the view that man is capable of attaining to almost any degree of sublimation, in spite of the existence of an immensity of proof against any such presumption. His optimism in respect of the results of the treatment of alcoholism and drug addiction will doubtless shock many workers in the same field, particularly in view of the crudity of the procedure which he advocates. Dr. Brown has a good deal to say on the psychology of peace and war, but omits any reference to the most penetrating study that exists on the subject in the English language, namely, 'Instincts of the Herd in Peace and War' by W. Trotter. In his chapter on 'Relation of Mind to Brain', the author shows himself to be under the spell of the fascinating philosophy of Bergson and so oblivious to the damaging criticisms to which its difficulties lay it open. The book is supplied with a copious bibliography and a tolerably good index.

O. B.-H.

\section{THE HISTAMINE AND INSULIN TREATMENT OF SCHIZOPHRENIA AND OTHER MENTAL DISEASES.-By Horace Hill, M.R.C.P. 1940. Baillière, Tindall and Cox, London. Pp. vii plus 133. Price, 6s.}

THIs is a very informative little book on the subject with which it deals. The writer points out that histamine is present in the body in any and every variety of shock and that a lot of the poisonous symptoms seen during shock therapy can be shown to be a mixture of the symptoms produced by poisonous doses of *insulin and histamine. This induced the author to employ non-toxic doses of insulin and histamine. By this method the patient gets small repeated shocks and no 'fit'. 'This form of treatment is particularly favourable in its action on cases of long-standing. According to the author it is important to remember that histamine acts differently in different circumstances but always the same way under the same circumstances. As the dose suitable to each case varies so much, the author recommends keeping small quantities of the fluid of various strengths to be injected. The standard dose is $0.5 \mathrm{mgm}$. The indications for the correct dosage are the sensations of the patient and the extent and duration of the flush to which histamine gives rise, along with the pulse and respiration rates. The author recommends using three phials each containing one fluid ounce of mixtures of insulin and histamine. The amount of insulin used is $\mathbf{5}$ units while the amounts of histamine are $0.5 \mathrm{mgm} ., 1 \mathrm{mgm}$, and $1.5 \mathrm{mgm}$. Each dose is 5 minims. When the appropriate dose is found, it may be given daily for a week and then on alternate days. The author gives a number of case histories in illustration of the type of cases treated and the results obtained.

\section{O. B.-H.}

MY LIFE.-By Havelock Ellis. 1940. William Heineman, Limited, London. Pp. xviii plus 542. Price, 15s.

IN the preface to this book the author states that he began to write his biography as far back as 1899 and that he chose his 'Finest moments' in which to write it. The son of a sea captain, Havelock Ellis always entertained a strong liking for the the ships upon it. When seven years old he went round the world in his father's ship and at the age of sixteen he went to Australia, once more on board his father's ship. In Australia he spent four happy years mostly as a school master and during a part of this period in a very lonely place called Sparkes Creek in New South Wales. Here he read and pondered over life as he saw it. He read enormously from early boyhood and throughout his life. He acquired a considerable knowledge of French literature and published in 1935 a study of French literature under the title From Rousseau to Proust. On his return to England he decided to become a doctor and joined St. Thomas Hospital in London. In spite of his great intellectual gifts he had great difficulty in passing his examinations to qualify, so that it was not until seven years had passed that he took the Licentiate in Medicine, Surgery and Midwifery of the Society of Apothecaries. During the whole of the period of his medical education Ellis was deeply engaged in various forms of literary work. It was about this time that he became acquainted with the works of James Hinton whose doctrines made a profound impression on Ellis. In 1883 he made the acquaintance with the woman who played an immense part in his life, Olive Schreiner, the talented authoress of that remarkable novel, The Story of an African Farm. Ellis and Olive Schreiner became very devoted to each other and their friendship lasted long after each of them married. In 1891 Ellis married Edith Lees, a brilliant woman with much talent for public speaking and writing. Although sexually an invert, she did nevertheless make Ellis a devoted wife until her mental balance broke down never completely to be re-established. In 1898 the famous Bedborough trial was held in the London Central Criminal Court. The trial arose through a man named George Bedborough selling a copy of the first volume of Ellis' Psychology of Sex which dealt with sexual inversion. Bedborough pleaded guilty and after a long and wearisome trial was bound over in the sum of $£ 100$ to come up for judgment, when called upon. The proceedings were a reflection on the law of England and to some extent on the medical profession of England for no eminent English doctor had the courage to come forward and attest in court as to the scientific value of Ellis' book. The Psychology of Sex was doubtless Ellis' magnum opus but his exquisite prose is not to be found therein but in later works, notably The Dance of Life. Though afflicted at times with much sorrow and anxiety, Ellis testifies to much happiness in his life which ended in 1939. A few months before there died another great exponent of sexual psychology, Sigmund Freud.

$$
\text { O. B-H. }
$$

A TEXTBOOK OF MEDICAL JURISPRUDENCE AND TOXICOLOGY.-By Ral Bahadur Jaising P. Modi, L.R.C.P. \& S. (Edin.), L.R.F.P.S. (Glas.). Sixth Edition. 1940. Butterworth and Company (India), Limited, Incorporated in England, Phœnix Building, Graham Road, Ballard Estate, Bombay. Pp. 820 plus civ, with 3 plates ( 2 coloured) and 158 illustrations in the text. Price, Rs. 15

THis excellent book by one of the pioneers in the field of forensic medicine in India has been thoroughly revised. All points referred to in the review in this paper on the last edition have received attention.

In the description of the picture of blood groups $a$ and $b$ should be $a$ and $b$. In the technique of grouping 